Concentrations of Tritium and Strontium-90 in Water from Selected Wells at the Idaho National Engineering Laboratory After Purging One, Two, and Three Borehole Volumes

By Roy C. Bartholomay

U.S. GEOLOGICAL SURVEY

Water Resources Investigations Report 93-4201

prepared in cooperation with the

U.S. DEPARTMENT OF ENERGY

Idaho Falls, Idaho

1993
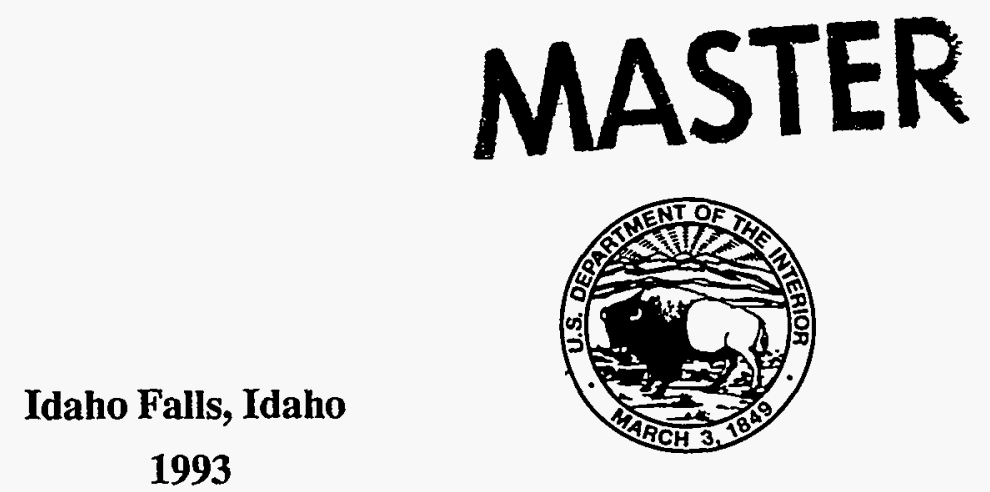

DE. 


\section{U.S. DEPARTMENT OF THE INTERIOR \\ BRUCE BABBITT, Secretary}

U.S. GEOLOGICAL SURVEY

Robert M. Hirsch, Acting Director

For additional information write to:

Project Chief

U.S. Geological Survey

INEL, MS 4148

P.O. Box 2230

Idaho Falls, ID 83403
Copies of this report can be purchased from:

U.S. Geological Survey

Earth Science Information Center

Open-File Reports Section

Box 25286, MS 517

Denver Federal Center

Denver, CO 80225 


\section{DISCLAIMER}

This report was prepared as an account of work sponsored by an agency of the United States Government. Neither the United States Government nor any agency thereof, nor any of their employees, make any warranty, express or implied, or assumes any legal liability or responsibility for the accuracy, completeness, or usefulness of any information, apparatus, product, or process disclosed, or represents that its use would not infringe privately owned rights. Reference herein to any specific commercial product, process, or service by trade name, trademark, manufacturer, or otherwise does not necessarily constitute or imply its endorsement, recommendation, or favoring by the United States Government or any agency thereof. The views and opinions of authors expressed herein do not necessarily state or reflect those of the United States Government or any agency thereof. 


\section{DISCLAIMER}

Portions of this document may be illegible in electronic image products. Images are produced from the best available original document. 


\section{CONTENTS}

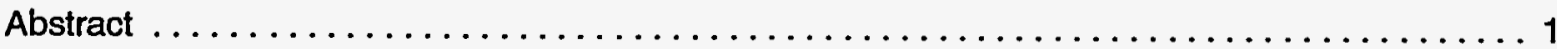

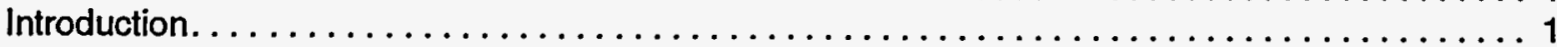

Previous investigations $\ldots \ldots \ldots \ldots \ldots \ldots \ldots \ldots \ldots \ldots \ldots \ldots \ldots \ldots$

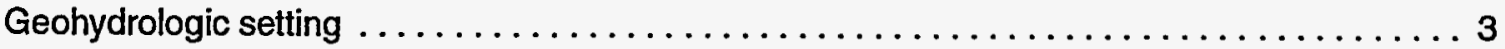

Acknowledgments . . . . . . . . . . . . . . . . . . . . . . . . . . 4

Methods of study $\ldots \ldots \ldots \ldots \ldots \ldots \ldots \ldots \ldots \ldots \ldots \ldots \ldots \ldots \ldots \ldots$

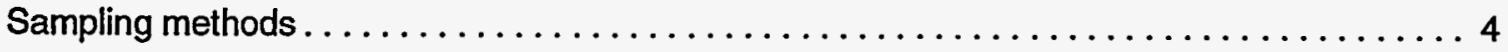

Analytical methods. . . . . . . . . . . . . . . . . . . . . . . . . . .

Guidelines for the interpretation of analytical results $\ldots \ldots \ldots \ldots \ldots \ldots \ldots$

Statistical analysis . . . . . . . . . . . . . . . . . . . . . . . . . 9

Concentrations of tritium and strontium-90. . . . . . . . . . . . . . . .

Conclusions . . ..................................... 10

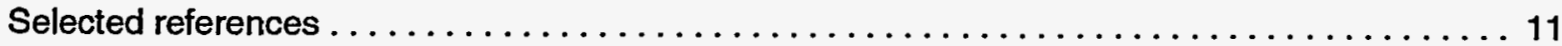

\section{FIGURES}

1-2. Maps showing:

1. Location of the Idaho National Engineering Laboratory and selected facilities . . . . . . . 2

2. Location of selected wells at the Idaho National Engineering Laboratory.......... 5

\section{TABLES}

1. Construction data and water levels for selected wells, Idaho National Engineering

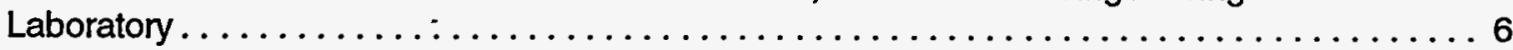

2. Results of field measurements for $\mathrm{pH}$, specific conductance, and temperature of water from selected wells, Idaho National Engineering Laboratory $\ldots \ldots \ldots \ldots \ldots \ldots \ldots 7$

3. Tritium and strontium-90 concentrations and associated analytical uncertainties in water from selected wells, Idaho National Engineering Laboratory $\ldots \ldots \ldots \ldots \ldots \ldots \ldots 12$

4. Statistical comparison of tritium concentrations and associated analytical uncertainties after purging one and three borehole volumes of water from selected wells, Idaho

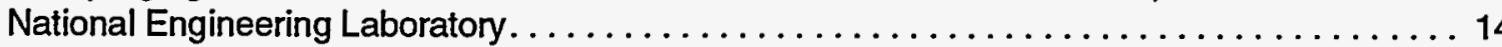

5. Statistical comparison of tritium concentrations and associated analytical uncertainties after purging two and three borehole volumes of water from selected wells, Idaho National Engineering Laboratory. . . . . . . . . . . . . . . . . . . . . 16

6. Statistical comparison of strontium-90 concentrations and associated analytical uncertainties after purging one and three borehole volumes of water from selected wells, Idaho National Engineering Laboratory. . . . . . . . . . . . . . . . . . . 18

7. Statistical comparison of strontium-90 concentrations and associated analytical uncertainties after purging two and three borehole volumes of water from selected wells, Idaho National Engineering Laboratory. 
CONVERSION FACTORS AND VERTICAL DATUM

\begin{tabular}{rll}
\hline Multiply & By & To Obtain \\
\hline inch (in.) & 25.4 & millimeter \\
foot (ft) & 0.3048 & meter \\
mile (mi) & 1.609 & kilometer \\
square mile (mi $\left.{ }^{2}\right)$ & 2.590 & square kilometer \\
gallon per minute (gal/min) & 3.785 & liter per minute \\
curie (Ci) & $3.70 \times 10^{10}$ & becquerel \\
picocurie per liter (pCi/L) & 0.037 & becquerel per liter \\
\hline
\end{tabular}

Temperature can be converted from degrees Celsius $\left({ }^{\circ} \mathrm{C}\right)$ to degrees Fahrenheit $\left({ }^{\circ} \mathrm{F}\right)$ by the equation: ${ }^{\circ} \mathrm{F}=\left({ }^{\circ} \mathrm{C} \times 1.8\right)+32$

Sea level: In this report, "sea level" refers to the distance above or below National Geodetic Vertical Datum of 1929-a geodetic datum derived from a general adjustment of the first-order level nets of the United States and Canada, formerly called Sea Level Datum of 1929. 


\title{
Concentrations of Tritium and Strontium-90 in Water from Selected Wells at the Idaho National Engineering Laboratory after Purging One, Two, and Three Borehole Volumes
}

\author{
By Roy C. Bartholomay
}

\section{Abstract}

Water from 11 wells completed in the Snake River Plain aquifer at the Idaho National Engineering Laboratory was sampled as part of the U.S. Geological Survey's quality assurance program to determine the effect of purging different borehole volumes on tritium and strontium-90 concentrations. Wells were selected for sampling on the basis of the length of time it took to purge a borehole volume of water. Samples were collected after purging one, two, and three borehole volumes. The U.S. Department of Energy's Radiological and Environmental Sciences Laboratory provided analytical services. Statistics were used to determine the reproducibility of analytical results.

The comparison between tritium and strontium- 90 concentrations after purging one and three borehole volumes and two and three borehole volumes showed that all but two sample pairs with defined numbers were in statistical agreement. Results indicate that concentrations of tritium and strontium-90 are not affected measurably by the number of borehole volumes purged.

\section{INTRODUCTION}

The Idaho National Engineering Laboratory (INEL), encompassing about $890 \mathrm{mi}^{2}$ of the eastern Snake River Plain in southeastern Idaho (fig. 1), is operated by the U.S. Department of Energy. INEL facilities are used in the development of peacetime atomic-energy applications, nuclear safety research, defense programs, and advanced energy concepts. Liquid-waste disposal has resulted in detectable concentrations of several waste constituents in water in the Snake River Plain aquifer underlying the INEL. From 1952 through 1990 , about $31,200 \mathrm{Ci}$ of tritium and $140 \mathrm{Ci}$ of strontium-90 were contained in wastewater disposed to wells and infiltration ponds at the INEL. The U.S. Geological Survey's INEL Project Office provides an independent assessment of the migration and fate of waste constituents in water in the Snake River Plain aquifer.

Prior to formal implementation of a quality assurance plan at the INEL Project Office in 1989, three borehole volumes of water were not consistently purged from some wells before sample collection. The quality assurance plan (Mann, L.J., written commun.,1989) states that water samples be collected after a minimum of three borehole volumes of water are purged and $\mathrm{pH}$, specific conductance, and water temperature measurements stabilize. Because of different purge rates used prior to 1989 , a study was needed to compare 


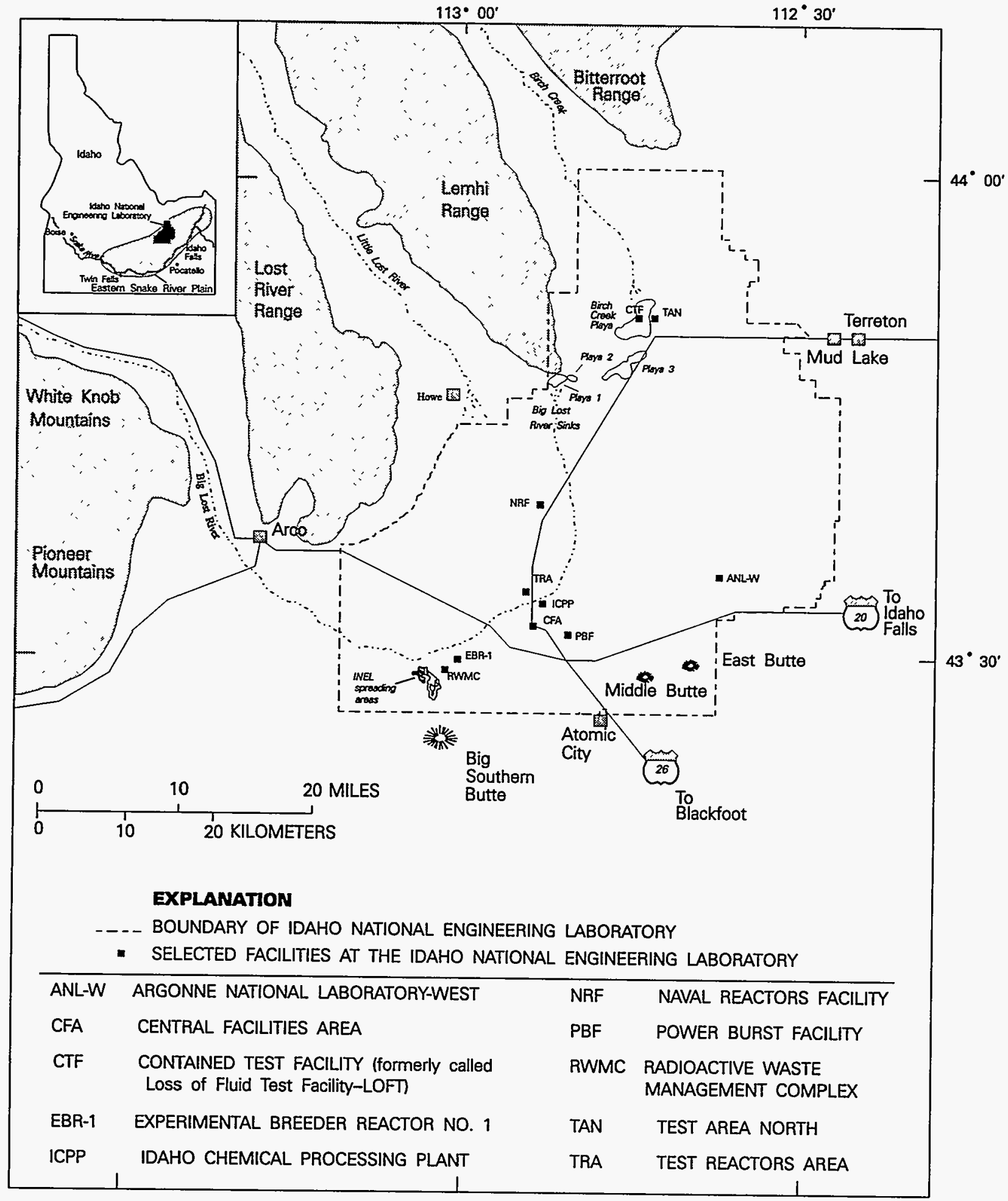

Figure 1.--Location of the Idaho National Engineering Laboratory and selected facilities. 
concentrations of various constituents after purging different borehole volumes.

This study was done as part of the INEL Project Office's quality assurance program to determine the effect of purging different borehole volumes on tritium and strontium-90 concentrations in ground water. Samples were collected and analyzed for tritium and strontium-90 after purging one, two, and three borehole volumes. The U.S. Department of Energy's Radiological and Environmental Sciences Laboratory (RESL) provided analytical services.

\section{Previous Investigations}

Dumouchelle and others (1990), Gibs and others (1990), and Herzog and others (1991) provide a comprehensive list of references for sampling ground water based on different purge rates; however, the effect of purging on tritium and strontium-90 concentrations in ground-water samples has not been studied previously. Three philosophies (Herzog and others, 1991, p. 465) for determining the volume of water that should be purged from a monitoring well prior to sampling appear in the literature. The first specifies that a given number of borehole volumes be purged, the second suggests purging until certain field parameters have stabilized, and the third specifies that the purge volume should be based on the hydraulic performance of the well. Suggested numbers of borehole volumes to be purged from a well prior to sampling range from less than 1 to more than 20.

\section{Geohydrologic Setting}

The eastern Snake River Plain is a northeasttrending structural basin about $200 \mathrm{mi}$ long and 50 to $70 \mathrm{mi}$ wide (fig. 1). The basin, bounded by faults on the northwest and downwarping and faulting on the southeast, has been filled with basaltic lava flows interbedded with terrestrial sediments (Whitehead, 1986). Individual basalt flows average 20 to $25 \mathrm{ft}$ in thickness with an aggregate thickness in places of several thousand feet. In areas of alluvial fan deposits, the sediments are composed primarily of sand and gravel, whereas in the areas where streams were dammed by basalt flows, the sediments are predominantly silt and clay (Garabedian, 1986). The basaltic lava flows and interbedded sedimentary deposits combine to form the Snake River Plain aquifer, which is the main source of water on the plain. The altitude of the water table for the Snake River Plain aquifer in July 1988 ranged from about 4,590 ft above sea level in the northern part of the INEL to about 4,420 ft in the southern part (Orr and Cecil, 1991, p. 25). The corresponding depths to water below land surface ranged from about $200 \mathrm{ft}$ in the northern part of the INEL to more than $900 \mathrm{ft}$ in the southeastern part.

Recharge to the Snake River Plain aquifer is principally from infiltration of applied irrigation water, infiltration of streamflow, and ground-water inflow from adjoining mountain drainage basins. Some recharge may occur from direct infiltration of precipitation, although the small annual precipitation ( 8 in. at the INEL), evapotranspiration, and the depth to water (in places exceeding $900 \mathrm{ft}$ ) probably minimize this source of recharge (Orr and Cecil, 1991, p. 22-23).

The Big Lost River drains more than $1,400 \mathrm{mi}^{2}$ of mountainous area that includes parts of the Lost River Range and the Pioneer and White Knob Mountains west of the INEL (fig. 1). Flow in the Big Lost River infiltrates to the Snake River Plain aquifer along its channel and at sinks and playas. Since 1958, excess runoff has been diverted to spreading areas in the southwestern part of the INEL, where much of the water rapidly infiltrates to the aquifer. Other surface drainages that recharge the Snake River Plain aquifer at the INEL include Birch Creek and the Little Lost River (fig. 1) (Orr and Cecil, 1991, p. 23). 


\section{Acknowledgments}

The author is grateful to personnel of the U.S. Department of Energy's RESL, Analytical Chemistry Branch-Don B. Martin, Chief-for analyzing the water samples and Denise $\mathrm{H}$. Dumouchelle and Steven R. Hannula of the U.S. Geological Survey for technically reviewing the manuscript.

\section{METHODS OF STUDY}

\section{Sampling Methods}

The methods used in sampling for tritium and strontium-90 generally followed guidelines established by the U.S. Geological Survey (Thatcher and others, 1977). Samples were collected at 11 monitoring wells equipped with dedicated submersible pumps (fig. 2). Because of the construction of several wells at the INEL, it takes several hours to purge one borehole volume of water. The 11 wells selected for this study were part of the routine sampling program and were chosen on the basis of the amount of time it takes to purge one borehole volume of water. The wells selected all required more than 1 hour to purge a borehole volume of water. The borehole volume was calculated by multiplying the cross-sectional area of the drilled borehole by the height of the column of water in the well. Construction data and water levels of wells sampled in this study are given in table 1.

For sample collection, a portable discharge line was attached at the wellhead. The line was $1.5 \mathrm{in}$. inside diameter galvanized-steel pipe with a stainless-steel sampling line attached at a $T$-joint so that excess discharge could be directed away from the sampling location. Brass valves were used between the wellhead and the $\mathrm{T}$-joint to aid in flow control. All pipes and fittings were rinsed with deionized water before they were attached at the wellhead. The lines then were flushed with water from the well and samples were collected after purging one, two, and three borehole volumes.

After collection, sample containers were sealed with laboratory film, labeled, and stored under secured conditions until they were hand-delivered to the RESL. Conditions at the wells during sample collection were recorded in a field logbook and chain-of-custody records were used to track samples from the time of collection until delivery to the RESL. These records are available for inspection at the INEL Project Office. The results of field measurements for $\mathrm{pH}$, specific conductance, and water temperature after each borehole volume was purged are listed in table 2 .

\section{Analytical Methods}

Water samples were analyzed for tritium and strontium- 90 by the RESL as described by Bodnar and Percival (1982). The direct liquid-scintillation counting method was used to analyze for tritium; the beta-counting method was used to analyze for dissolved strontium-90.

\section{Guidelines for the Interpretation of Analytical Results}

Concentrations of tritium and strontium-90 are reported with an estimated sample standard deviation, $\mathbf{s}$, that is obtained by propagating sources of analytical uncertainty in measurements. The following guidelines for interpreting analytical results are based on an extension of a method proposed by Currie (1984).

In the analysis for a particular radionuclide, laboratory measurements are made on a target sample and a prepared blank. Instrument signals for the sample and the blank vary randomly. Therefore, it is essential to distinguish between two key aspects of the problem of detection: (1) The instrument signal for the sample must be larger than the signal observed for the blank before the decision can be made that the radionuclide was detected; and (2) an estimation must be made of the 


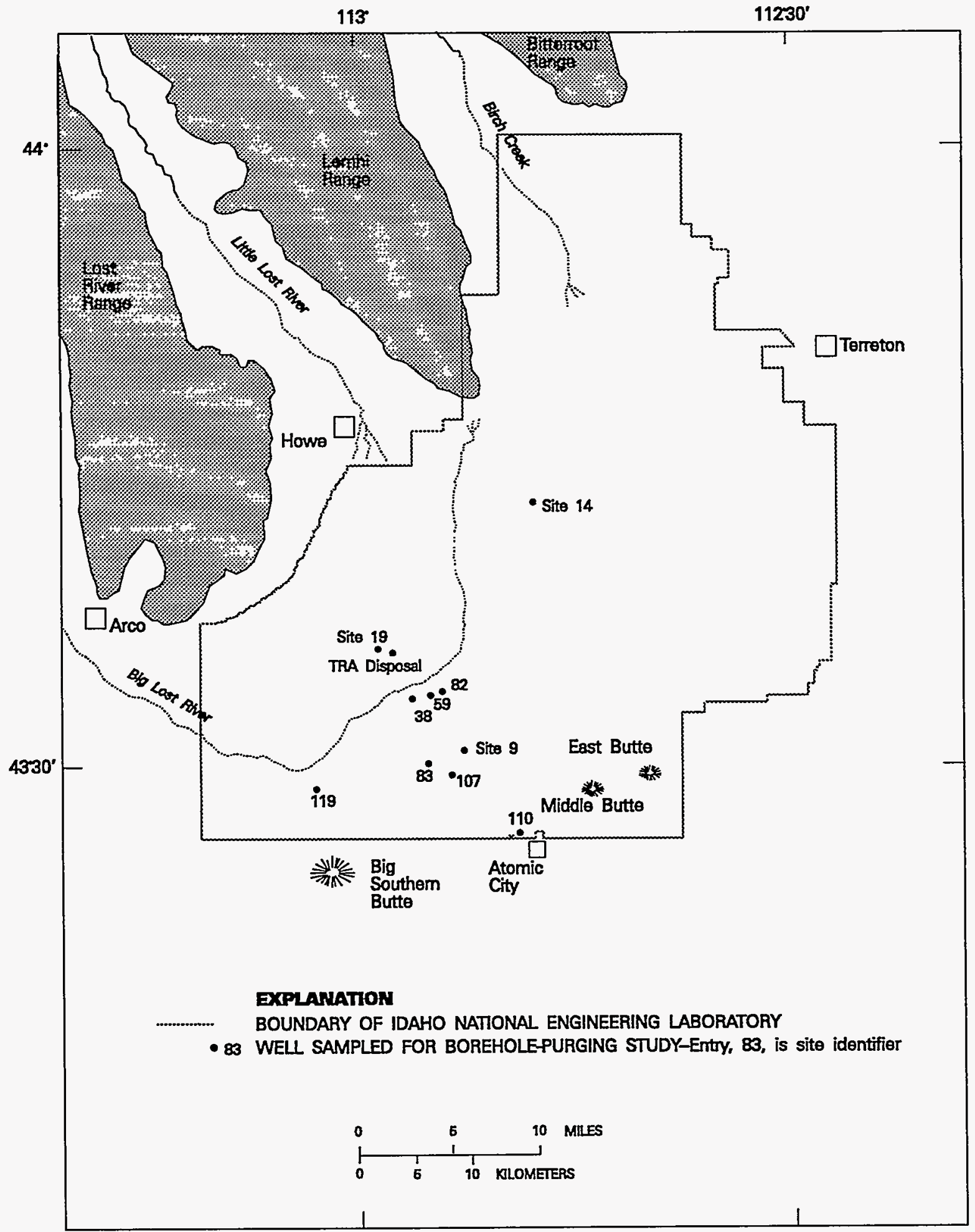

Figure 2.-Location of selected wells at the Idaho National Engineering Laboratory. 
Table 1.-Construction data and water levels for selected wells, Idaho National Engineering Laboratory

[See figure 2 for location of wells. Pump setting, Openings, Depth of well, and Depth to water rounded to nearest foot below land surface. Water level measurements from April and October 1991, respectively. Discharge in gallons per minute. Borehole diameters are in inches and are given for the part of well below the water level]

\begin{tabular}{|c|c|c|c|c|c|c|c|}
\hline \multirow{2}{*}{$\begin{array}{c}\text { Well } \\
\text { identifier }\end{array}$} & \multirow{2}{*}{$\begin{array}{l}\text { Pump } \\
\text { setting }\end{array}$} & \multicolumn{2}{|c|}{ Openings } & \multirow{2}{*}{$\begin{array}{l}\text { Depth } \\
\text { of well }\end{array}$} & \multirow{2}{*}{$\begin{array}{l}\text { Depth } \\
\text { to water }\end{array}$} & \multirow[b]{2}{*}{ Discharge } & \multirow[b]{2}{*}{ Borehole diameter } \\
\hline & & Type & Interval & & & & \\
\hline Site 9 & 523 & Open hole & $681-1,057$ & 1,057 & $471 ; 473$ & 25 & 10 \\
\hline Site 14 & 318 & Open hole & $535-717$ & 717 & $266 ; 271$ & 11 & $\begin{array}{l}12(0 \text { to } 340 \mathrm{ft}) \\
10(340 \text { to } 377 \mathrm{ft}) \\
8(377 \text { to } 717 \mathrm{ft})\end{array}$ \\
\hline Site 19 & 486 & Perforated & $472-862$ & 865 & $467 ; 469$ & 25 & $\begin{array}{l}18(183 \text { to } 576 \mathrm{ft}) \\
10(576 \text { to } 865 \mathrm{ft})\end{array}$ \\
\hline $\begin{array}{l}\text { TRA } \\
\text { Disposal }\end{array}$ & 507 & Perforated & $515-1,267$ & 1,267 & 466 & 25 & 12 \\
\hline 38 & 523 & Open hole & $678-729$ & 729 & $471 ; 473$ & $3,3.5$ & $\begin{array}{l}8(156 \text { to } 505 \mathrm{ft}) \\
6(505 \text { to } 729 \mathrm{ft})\end{array}$ \\
\hline 59 & 490 & Open hole & $464-657$ & 657 & $455 ; 456$ & 4,3 & 6 \\
\hline 82 & 510 & $\begin{array}{l}\text { Perforated } \\
\text { Open hole }\end{array}$ & $\begin{array}{l}470-520 \\
593-700\end{array}$ & 700 & $448 ; 450$ & 6 & 8 \\
\hline 83 & 606 & Open hole & $516-752$ & 752 & $497 ; 498$ & 6 & 6 \\
\hline 107 & 509 & Open hole & $270-690$ & 690 & $479 ; 480$ & 5 & 8 \\
\hline 110 & 612 & Perforated & $580-780$ & 780 & $569 ; 570$ & 5 & 8 \\
\hline 119 & 685 & Perforated & $639-705$ & 705 & $605 ; 606$ & 3 & 8 \\
\hline
\end{tabular}


Table 2.-Results of field measurements for $\mathrm{pH}$, specific conductance, and temperature of water from selected wells, Idaho National Engineering Laboratory

[See figure 2 for location of wells. Date sampled, month/day/year; $\mathrm{pH}$, negative base-10 logarithm of hydrogen ion activity in moles per liter; specific conductance, microsiemens per centimeter at $25^{\circ} \mathrm{C}$ (degrees Celsius); temperature, $\left.{ }^{\circ} \mathrm{C}\right]$

\begin{tabular}{|c|c|c|c|c|c|}
\hline $\begin{array}{l}\text { Well } \\
\text { identifier }\end{array}$ & $\begin{array}{c}\text { Date } \\
\text { sampled }\end{array}$ & Time & $\mathrm{pH}$ & $\begin{array}{c}\text { Specific } \\
\text { conductance }\end{array}$ & Temperature \\
\hline Site 9 & $\begin{array}{l}4 / 9 / 91 \\
9 / 27 / 91\end{array}$ & $\begin{array}{l}1050 \\
1240 \\
1431 \\
1145 \\
1320 \\
1456\end{array}$ & $\begin{array}{l}8.3 \\
8.1 \\
8.1 \\
8.1 \\
8.1 \\
8.1\end{array}$ & $\begin{array}{l}342 \\
340 \\
345 \\
352 \\
352 \\
367\end{array}$ & $\begin{array}{l}13.5 \\
14.0 \\
14.0 \\
14.0 \\
14.0 \\
14.5\end{array}$ \\
\hline Site 14 & $\begin{array}{l}4 / 24 / 91 \\
10 / 18 / 91\end{array}$ & $\begin{array}{l}1105 \\
1355 \\
1646 \\
1136 \\
1422 \\
1709\end{array}$ & $\begin{array}{l}8.0 \\
8.0 \\
8.0 \\
7.9 \\
7.9 \\
7.9\end{array}$ & $\begin{array}{l}329 \\
330 \\
330 \\
331 \\
335 \\
331\end{array}$ & $\begin{array}{l}17.0 \\
17.0 \\
17.0 \\
17.0 \\
17.0 \\
17.0\end{array}$ \\
\hline Site 19 & $\begin{array}{l}4 / 2 / 91 \\
10 / 22 / 91\end{array}$ & $\begin{array}{l}1020 \\
1155 \\
1331 \\
1424 \\
1558 \\
1733\end{array}$ & $\begin{array}{l}8.0 \\
8.0 \\
7.9 \\
7.9 \\
7.9 \\
7.9\end{array}$ & $\begin{array}{l}388 \\
390 \\
390 \\
389 \\
392 \\
392\end{array}$ & $\begin{array}{l}15.0 \\
15.0 \\
15.0 \\
14.5 \\
14.5 \\
14.5\end{array}$ \\
\hline TRA Disposal & $10 / 30 / 91$ & $\begin{array}{l}1025 \\
1335 \\
1646\end{array}$ & $\begin{array}{l}7.6 \\
7.7 \\
7.7\end{array}$ & $\begin{array}{l}465 \\
470 \\
470\end{array}$ & $\begin{array}{l}12.5 \\
14.0 \\
13.5\end{array}$ \\
\hline 38 & $\begin{array}{l}4 / 22 / 91 \\
10 / 3 / 91\end{array}$ & $\begin{array}{l}1100 \\
1310 \\
1521 \\
1035 \\
1230 \\
1431\end{array}$ & $\begin{array}{l}7.9 \\
7.9 \\
7.9 \\
7.9 \\
7.9 \\
7.9\end{array}$ & $\begin{array}{l}729 \\
739 \\
732 \\
730 \\
708 \\
708\end{array}$ & $\begin{array}{l}14.5 \\
14.5 \\
14.5 \\
15.0 \\
15.0 \\
15.0\end{array}$ \\
\hline 59 & $\begin{array}{l}4 / 4 / 91 \\
10 / 21 / 91\end{array}$ & $\begin{array}{l}1005 \\
1120 \\
1236 \\
1100 \\
1240 \\
1421\end{array}$ & $\begin{array}{l}8.7 \\
8.5 \\
8.4 \\
8.1 \\
8.1 \\
8.1\end{array}$ & $\begin{array}{l}475 \\
491 \\
485 \\
860 \\
902 \\
915\end{array}$ & $\begin{array}{l}14.5 \\
14.5 \\
14.5 \\
14.5 \\
15.0 \\
14.5\end{array}$ \\
\hline
\end{tabular}


Table 2.-Results of field measurements for $\mathrm{pH}$, specific conductance, and temperature of water from selected wells, Idaho National Engineering Laboratory-Continued

\begin{tabular}{|c|c|c|c|c|c|}
\hline $\begin{array}{l}\text { Well } \\
\text { identifier }\end{array}$ & $\begin{array}{c}\text { Date } \\
\text { sampled }\end{array}$ & Time & $\mathrm{pH}$ & $\begin{array}{c}\text { Specific } \\
\text { conductance }\end{array}$ & Temperature \\
\hline 82 & $\begin{array}{l}3 / 27 / 91 \\
10 / 23 / 91\end{array}$ & $\begin{array}{l}1035 \\
1225 \\
1416 \\
1104 \\
1253 \\
1443\end{array}$ & $\begin{array}{l}8.0 \\
8.0 \\
8.0 \\
8.0 \\
8.0 \\
8.0\end{array}$ & $\begin{array}{l}358 \\
350 \\
350 \\
348 \\
348 \\
340\end{array}$ & $\begin{array}{l}12.0 \\
12.0 \\
12.0 \\
12.0 \\
12.0 \\
12.0\end{array}$ \\
\hline 83 & $\begin{array}{l}3 / 25 / 91 \\
10 / 1 / 91\end{array}$ & $\begin{array}{l}1240 \\
1345 \\
1451 \\
1007 \\
1109 \\
1212\end{array}$ & $\begin{array}{l}7.8 \\
7.8 \\
7.8 \\
8.0 \\
8.0 \\
8.0\end{array}$ & $\begin{array}{l}278 \\
280 \\
282 \\
280 \\
289 \\
291\end{array}$ & $\begin{array}{l}12.0 \\
11.5 \\
11.5 \\
12.0 \\
12.0 \\
12.0\end{array}$ \\
\hline 107 & $\begin{array}{l}4 / 22 / 91 \\
9 / 30 / 91\end{array}$ & $\begin{array}{l}1120 \\
1310 \\
1506 \\
1135 \\
1325 \\
1516\end{array}$ & $\begin{array}{l}8.0 \\
8.0 \\
8.1 \\
8.0 \\
8.0 \\
8.0\end{array}$ & $\begin{array}{l}392 \\
392 \\
399 \\
390 \\
398 \\
395\end{array}$ & $\begin{array}{l}15.5 \\
15.5 \\
15.5 \\
15.0 \\
15.0 \\
15.0\end{array}$ \\
\hline 110 & $\begin{array}{l}3 / 26 / 91 \\
10 / 7 / 91\end{array}$ & $\begin{array}{l}1120 \\
1310 \\
1501 \\
1405 \\
1555 \\
1746\end{array}$ & $\begin{array}{l}8.1 \\
8.1 \\
8.1 \\
8.0 \\
8.0 \\
8.0\end{array}$ & $\begin{array}{l}374 \\
380 \\
383 \\
379 \\
379 \\
375\end{array}$ & $\begin{array}{l}14.0 \\
14.0 \\
14.0 \\
14.0 \\
14.5 \\
14.5\end{array}$ \\
\hline 119 & $\begin{array}{l}4 / 19 / 91 \\
10 / 15 / 91\end{array}$ & $\begin{array}{l}1030 \\
1200 \\
1331 \\
1030 \\
1155 \\
1321\end{array}$ & $\begin{array}{l}8.5 \\
8.4 \\
8.4 \\
8.8 \\
8.6 \\
8.4\end{array}$ & $\begin{array}{l}270 \\
270 \\
275 \\
265 \\
278 \\
280\end{array}$ & $\begin{array}{l}14.0 \\
14.5 \\
14.5 \\
14.0 \\
15.0 \\
15.5\end{array}$ \\
\hline
\end{tabular}


minimum radionuclide concentration that will yield a sufficiently large observed signal before the correct decision can be made for detection or nondetection of the radionuclide. The first aspect of the problem is a qualitative decision based on an observed signal and a definite criterion for detection. The second aspect of the problem is an estimation of the detection capabilities of a given measurement process.

In the laboratory, instrument signals must exceed a critical level before the qualitative decision can be made as to whether the radionuclide was detected. Radionuclide concentrations that equal $1.6 \mathrm{~s}$ meet this criterion; at $1.6 \mathrm{~s}$, there is a 95-percent probability that the correct conclusion-not detected-will be made. Given a large number of samples, as many as 5 percent of the samples with measured concentrations larger than or equal to $1.6 \mathrm{~s}$, which were concluded as being detected, might not contain the radionuclide. These measurements are referred to as false positives and are errors of the first kind in hypothesis testing.

Once the critical level of $1.6 \mathrm{~s}$ has been defined, the minimum detectable concentration may be determined. Radionuclide concentrations that equal $3 \mathrm{~s}$ represent a measurement at the minimum detectable concentration. For true concentrations of $3 \mathrm{~s}$ or larger, there is a 95-percent or larger probability that the radionuclide was detected in a sample. In a large number of samples, the conclusion-not detected-will be made in 5 percent of the samples that contain true concentrations at the minimum detectable concentration of $3 \mathbf{s}$. These measurements are referred to as false negatives and are errors of the second kind in hypothesis testing.

True radionuclide concentrations between $1.6 \mathrm{~s}$ and $3 \mathrm{~s}$ have larger errors of the second kind. That is, there is a larger-than-5-percent probability of false negative results for samples with true concentrations between 1.6s and 3s. Although the radionuclide might have been detected, such detection may not be considered reliable; at $1.6 \mathrm{~s}$, the probability of a false negative is about 50 percent.

The critical level and minimum detectable concentration are based on counting statistics alone and do not include systematic or random errors inherent in laboratory procedures. The values $1.6 \mathrm{~s}$ and $3 \mathrm{~s}$ vary slightly with background or blank counts, with the number of gross counts for individual analyses, and for different radionuclides. In this report, radionuclide concentrations less than 3 s are considered to be below a "reporting level." The critical level, minimum detectable concentration, and reporting level aid the reader in the interpretation of analytical results and do not represent absolute concentrations of radioactivity which may or may not have been detected.

\section{Statistical Analysis}

Analytical results were compared using the following equations derived from the American Society for Testing and Materials (1988):

and $R=\frac{x}{y}$

$$
S_{R}=R\left[\left(S_{x}\right)^{2}+\left(S_{y}\right)^{2}\right]^{1 / 2}
$$

where

$$
\mathrm{R}=\text { ratio of analytical results, }
$$$$
\mathrm{X}=\text { radionuclide concentration after purging }
$$

one or two borehole volumes,

$$
\mathrm{y}=\text { radionuclide concentration after purging }
$$

three borehole volumes,

$\mathrm{S}_{\mathrm{R}}=$ uncertainty in the comparison of the analytical results,

$S_{x}=$ reported uncertainty as a decimal fraction of the analytical result for the water sample after purging one or two borehole volumes, and $S_{y}=$ reported uncertainty as a decimal fraction of the analytical result for the water sample after purging three borehole volumes.

If $R+2 S_{R}$ includes 1.0, there is a 95-percent probability that the analytical results are in statistical agreement. If $R+2 S_{R}$, does not include 1.0 , there is a 95 -percent probability that the analytical results are not in statistical agreement. 
These calculations determine reproducibility of the analytical results for water samples.

\section{CONCENTRATIONS OF TRITIUM AND STRONTIUM-90}

Concentrations of tritium and strontium-90 in ground water from each well are given in table 3 (at end of this report). Statistical comparisons of analytical results and uncertainties are given in tables 4-7 (at end of this report).

An undefined number in the $\mathrm{R}$ column of tables 4-7 indicates that the RESL reported a zero as the analytical result and equation 1 produced an undefined number. An undefined number does not imply that the pair of analytical results are not in statistical agreement. Only pairs of analytical results that produced a defined number from equations 1 and 2 were used for the determination of statistical agreement. An undefined number in the $2 S_{R}$ column indicates that either equation 1 produced an undefined number or the laboratory reported a zero as the analytical result.

Concentrations of tritium in ground water ranged from below the reporting level to $28,600 \pm 700 \mathrm{pCi} / \mathrm{L}$ (table 3 ). Comparison of tritium concentrations after purging one and three borehole volumes showed that all the sample pairs with defined numbers were in statistical agreement. Four sample pairs resulted in undefined numbers (table 4). Comparison of tritium concentrations after purging two and three borehole volumes showed that all but one sample pair with defined numbers were in statistical agreement (table 5). The tritium concentrations in the sample pair from well 59 (4/4/91) were not in statistical agreement; however, the sample pair collected after purging one and three borehole volumes were in statistical agreement.

Concentrations of strontium-90 in ground water ranged from below the reporting level to $29 \pm 3 \mathrm{pCi} / \mathrm{L}$ (table 3). Comparison of strontium-90 concentrations after purging one and three borehole volumes showed that all but one sample pair with defined numbers were in statistical agreement (table 6). Comparison of strontium-90 concentrations after purging two and three borehole volumes showed that all sample pairs with defined numbers were in statistical agreement (table 7). The samples from well $82(3 / 27 / 91)$ had concentrations less than the reporting level after purging one and two borehole volumes and a concentration greater than the reporting level after purging three borehole volumes. The historical trend of this well along with the samples collected on 10/23/91 show strontium-90 concentrations less than the reporting level, so a rerun of the sample collected after purging three borehole volumes was requested. The rerun showed that the strontium-90 concentration was $-1.6 \pm 1.6 \mathrm{pCi} / \mathrm{L}$, which is in statistical agreement with the other values.

\section{CONCLUSIONS}

Concentrations of tritium and strontium-90 in water samples from wells with purge times greater than 3 hours at the INEL are not affected measurably by purging either one, two, or three borehole volumes. The statistics presented here show reproducibility of analytical results in all but two sample pairs with defined numbers. Results for this study indicate that it is not necessary to purge three borehole volumes from wells with purge times greater than 3 hours; hence, data collected from the wells not purged three borehole volumes in the past are probably reliable. Three borehole volumes, however, should continue to be purged to ensure consistency in the data base. 


\section{SELECTED REFERENCES}

American Society for Testing and Materials, 1988, Standard practice for conducting an interlaboratory study to determine the precision of a test method: Philadelphia, Pa., E691-87, 20 p.

Bodnar, L.Z., and Percival, D.R., eds., 1982, Analytical Chemistry Branch Procedures ManualRadiological and Environmental Sciences Laboratory: U.S. Department of Energy Report IDO-12096, [363] p.

Cecil, L.D., Knobel, L.L., Wegner, S.J., and Moore, L.L., 1989, Evaluation of field sampling and preservation methods for strontium- 90 in ground water at the Idaho National Engineering Laboratory: U.S. Geological Survey WaterResources Investigations Report 89-4146 (DOE/ID-22083), 24 p.

Currie, L.A., 1984, Lower limits of detection: Definition and elaboration of a proposed position for radiological effluent and environmental measurements: U.S. Nuclear Regulatory Commission NUREG/CR-4007, $139 \mathrm{p}$.

Dumouchelle, D.H., Lynch, E.A., and Cummings, T.R., 1990, A literature survey of information on well installation and sample collection procedures used in investigations of ground-water contamination by organic compounds: U.S. Geological Survey Open-File Report 90-378, 60 p.

Garabedian, S.P., 1986, Application of a parameterestimation technique to modeling the regional aquifer underlying the eastern Snake River Plain, Idaho: U.S. Geological Survey Water-Supply Paper 2278, $60 \mathrm{p}$.

Gibs, Jacob, Imbrigiotta, T.E., and Turner, Kenneth, 1990, Bibliography on sampling ground water for organic compounds: U.S. Geological Survey Open-File Report 90-564, 22 p.

Hardy, M.A., Leahy, P.P., and Alley, W.M., 1989, Well installation and documentation, and ground-water sampling protocols for the pilot national waterquality assessment program: U.S. Geological Survey Open-File Report 89-396, 36 p.

Herzog, Beverly, Pennino, James, and Nielsen, G.L., 1991, Ground-water sampling, in Nielsen, D.M., ed., Practical handbook of ground-water monitoring: Chelsea, Mich., Lewis Publishers, p. 449-499.
Orr, B.R., and Cecil, L.D., 1991, Hydrologic conditions and distribution of selected chemical constituents in water, Snake River Plain aquifer, Idaho National Engineering Laboratory, Idaho, 1986 to 1988: U.S. Geological Survey Water-Resources Investigations Report 91-4047 (DOE/ID-22096), $56 \mathrm{p}$.

Thatcher, L.L., Janzer, V.J., and Edwards, K.W., 1977, Methods for determination of radioactive substances in water and fluvial sediments: U.S. Geological Survey Techniques of WaterResources Investigations, book 5, chap. A5, 95 p.

Wegner, S.J., 1989, Selected quality assurance data for water samples collected by the U.S. Geological Survey, Idaho National Engineering Laboratory, Idaho, 1980 to 1988: U.S. Geological Survey Water-Resources Investigations Report 89-4168 (DOE/ID-22085), $91 \mathrm{p}$.

Whitehead, R.L., 1986, Geohydrologic framework of the Snake River Plain, Idaho and eastern Oregon: U.S. Geological Survey Hydrologic Investigations Atlas HA-681, scale 1:1,000,000, 3 sheets. 
Table 3.-Tritium and strontium-90 concentrations and associated analytical uncertainties in water from selected wells, Idaho National Engineering Laboratory

[See figure 2 for location of wells. Analyses were performed by Department of Energy's Radiological and Environmental Sciences Laboratory. Analytical results and associated uncertainties are in picocuries per liter. Analytical uncertainties are reported as 1s. Date sampled, month/day/year]

\begin{tabular}{|c|c|c|c|c|}
\hline $\begin{array}{c}\text { Well } \\
\text { identifier }\end{array}$ & $\begin{array}{c}\text { Date } \\
\text { sampled }\end{array}$ & Time & Tritium & Strontium-90 \\
\hline Site 9 & $\begin{array}{l}4 / 9 / 91 \\
9 / 27 / 91\end{array}$ & $\begin{array}{l}1050 \\
1240 \\
1431 \\
1145 \\
1320 \\
1456\end{array}$ & $\begin{array}{r}10 \pm 160 \\
-110 \pm 160 \\
50 \pm 160 \\
10 \pm 170 \\
10 \pm 170 \\
-50 \pm 170\end{array}$ & $\begin{array}{c}-0.2 \pm 1.5 \\
.7 \pm 1.6 \\
-.8 \pm 1.5 \\
-5 \pm 2 \\
-6 \pm 2 \\
-6 \pm 2\end{array}$ \\
\hline Site 14 & $\begin{array}{l}4 / 24 / 91 \\
10 / 18 / 91\end{array}$ & $\begin{array}{l}1105 \\
1355 \\
1646 \\
1136 \\
1422 \\
1709\end{array}$ & $\begin{array}{r}50 \pm 160 \\
170 \pm 170 \\
-20 \pm 160 \\
0 \pm 200 \\
100 \pm 200 \\
-30 \pm 170\end{array}$ & $\begin{array}{c}-1.6 \pm 1.8 \\
0 \pm 2 \\
0 \pm 2 \\
0 \pm 2 \\
1 \pm 2 \\
1.3 \pm 2.4\end{array}$ \\
\hline Site 19 & $\begin{array}{l}4 / 2 / 91 \\
10 / 22 / 91\end{array}$ & $\begin{array}{l}1020 \\
1155 \\
1331 \\
1424 \\
1558 \\
1733\end{array}$ & $\begin{array}{r}110 \pm 160 \\
-40 \pm 160 \\
-50 \pm 160 \\
10 \pm 170 \\
0 \pm 200 \\
10 \pm 170\end{array}$ & $\begin{array}{c}1.7 \pm 2.0 \\
3 \pm 2 \\
1.1 \pm 1.9 \\
0 \pm 2 \\
4 \pm 2 \\
-1.3 \pm 2.3\end{array}$ \\
\hline TRA Disposal & $10 / 30 / 91$ & $\begin{array}{l}1025 \\
1335 \\
1646\end{array}$ & $\begin{array}{l}7,700 \pm 400 \\
7,300 \pm 400 \\
6,900 \pm 300\end{array}$ & $\begin{array}{r}-.9 \pm 1.7 \\
.8 \pm 1.6 \\
-.4 \pm 1.5\end{array}$ \\
\hline 38 & $\begin{array}{l}4 / 22 / 91 \\
10 / 3 / 91\end{array}$ & $\begin{array}{l}1100 \\
1310 \\
1521 \\
1035 \\
1230 \\
1431\end{array}$ & $\begin{array}{l}28,600 \pm 700 \\
28,600 \pm 700 \\
27,600 \pm 700 \\
25,600 \pm 700 \\
25,700 \pm 700 \\
26,300 \pm 700\end{array}$ & $\begin{array}{r}26 \pm 3 \\
28 \pm 3 \\
29 \pm 3 \\
23 \pm 3 \\
27 \pm 5 \\
9 \pm 3\end{array}$ \\
\hline 59 & $\begin{array}{l}4 / 4 / 91 \\
10 / 21 / 91\end{array}$ & $\begin{array}{l}1005 \\
1120 \\
1236 \\
1100 \\
1240 \\
1421\end{array}$ & $\begin{array}{r}5,300 \pm 300 \\
6,300 \pm 300 \\
4,900 \pm 300 \\
19,100 \pm 600 \\
18,900 \pm 600 \\
19,300 \pm 600\end{array}$ & $\begin{array}{l}13 \pm 3 \\
16 \pm 3 \\
13 \pm 3 \\
18 \pm 3 \\
17 \pm 3 \\
14 \pm 2\end{array}$ \\
\hline
\end{tabular}


Table 3.-Tritium and strontium-90 concentrations and associated analytical uncertainties in water from selected wells, Idaho National Engineering Laboratory-Continued

\begin{tabular}{|c|c|c|c|c|}
\hline $\begin{array}{l}\text { Well } \\
\text { identifier }\end{array}$ & $\begin{array}{c}\text { Date } \\
\text { sampled }\end{array}$ & Time & Tritium & Strontium-90 \\
\hline 82 & $\begin{array}{l}3 / 27 / 91 \\
10 / 23 / 91\end{array}$ & $\begin{array}{l}1035 \\
1225 \\
1416 \\
1104 \\
1253 \\
1443\end{array}$ & $\begin{array}{r}1,100 \pm 200 \\
1,200 \pm 200 \\
1,100 \pm 200 \\
150 \pm 170 \\
150 \pm 170 \\
100 \pm 200\end{array}$ & $\begin{array}{c}-3.1 \pm 1.7 \\
0 \pm 2 \\
8 \pm 2 \\
-1 \pm 2 \\
-1.2 \pm 2.1 \\
-2 \pm 2\end{array}$ \\
\hline 83 & $\begin{array}{l}3 / 25 / 91 \\
10 / 1 / 91\end{array}$ & $\begin{array}{l}1240 \\
1345 \\
1451 \\
1007 \\
1109 \\
1212\end{array}$ & $\begin{array}{r}-50 \pm 160 \\
-50 \pm 160 \\
20 \pm 160 \\
100 \pm 200 \\
-80 \pm 170 \\
0 \pm 200\end{array}$ & $\begin{array}{c}-3.7 \pm 1.5 \\
-4.4 \pm 1.5 \\
-3.8 \pm 1.5 \\
-1.4 \pm 1.9 \\
-2 \pm 2 \\
-2 \pm 2\end{array}$ \\
\hline 107 & $\begin{array}{l}4 / 22 / 91 \\
9 / 30 / 91\end{array}$ & $\begin{array}{l}1120 \\
1310 \\
1506 \\
1135 \\
1325 \\
1516\end{array}$ & $\begin{array}{r}110 \pm 160 \\
60 \pm 160 \\
-70 \pm 160 \\
100 \pm 200 \\
-80 \pm 170 \\
0 \pm 170\end{array}$ & $\begin{array}{r}-1 \pm 2 \\
-1 \pm 2 \\
-1 \pm 2 \\
1 \pm 2 \\
1 \pm 2 \\
2 \pm 2\end{array}$ \\
\hline 110 & $\begin{array}{l}3 / 26 / 91 \\
10 / 7 / 91\end{array}$ & $\begin{array}{l}1120 \\
1310 \\
1501 \\
1405 \\
1555 \\
1746\end{array}$ & $\begin{array}{r}210 \pm 170 \\
-170 \pm 150 \\
20 \pm 160 \\
-150 \pm 160 \\
100 \pm 200 \\
-30 \pm 170\end{array}$ & $\begin{array}{c}-3.6 \pm 1.7 \\
-1.2 \pm 2.0 \\
-3 \pm 2 \\
-1 \pm 2 \\
-1.0 \pm 2.2 \\
0 \pm 2\end{array}$ \\
\hline 119 & $\begin{array}{l}4 / 19 / 91 \\
10 / 15 / 91\end{array}$ & $\begin{array}{l}1030 \\
1200 \\
1331 \\
1030 \\
1155 \\
1321\end{array}$ & $\begin{array}{r}70 \pm 160 \\
150 \pm 170 \\
0 \pm 160 \\
150 \pm 170 \\
-130 \pm 160 \\
-140 \pm 160\end{array}$ & $\begin{array}{c}.7 \pm 1.7 \\
0 \pm 1.6 \\
4 \pm 2 \\
-1 \pm 2 \\
-3 \pm 2 \\
1.4 \pm 2.1\end{array}$ \\
\hline
\end{tabular}




\begin{tabular}{|c|c|c|c|c|c|c|c|c|}
\hline$\lambda$ & $60^{\circ}$ & $66^{\circ} 0$ & 009 & $00 \varepsilon^{\prime} 6 \mathrm{I}$ & 009 & 00 I‘6I & I6/IZ/0I & \\
\hline$\lambda$ & $8 \mathrm{I}^{\circ}$ & {$[\cdot I$} & $00 \varepsilon$ & $006^{6} t$ & $00 \varepsilon$ & $00 \varepsilon^{\prime} \varsigma$ & {$[6 / t / t$} & $6 \mathrm{~S}$ \\
\hline$x$ & $\angle 0^{\circ}$ & $\angle 6^{\circ}$ & $00 L$ & $00 \varepsilon^{\prime} 9 \tau$ & $00 L$ & $009^{\circ} \varsigma Z$ & I $6 / \varepsilon / 0[$ & \\
\hline$x$ & $\angle 0^{\circ}$ & $0 \tau$ & $00 L$ & $009^{\circ} \angle Z$ & $00 L$ & $009^{\circ} 8 z$ & $I 6 / \tau Z / /$ & $8 \varepsilon$ \\
\hline$x$ & $\mathrm{SI}^{\circ}$ & I’I & $00 \varepsilon$ & $006^{\circ} 9$ & $00 t$ & $00 L^{\prime} L$ & $\mathrm{I} 6 / 0 \varepsilon / 0 \mathrm{I}$ & IEsods!̣ $\forall \mathrm{d} \mathrm{L}$ \\
\hline$\lambda$ & $8 t$ & $0 . I$ & $0 L I$ & $0 \mathrm{I}$ & $0 L I$ & OI & I6/ZZ/0I & \\
\hline$\lambda$ & SI $^{-}$ & $z^{\prime} z^{-}$ & 09I & OS- & $09 I$ & OI I & {$[6 / 2 / \mathrm{t}$} & 6โ วI!S \\
\hline-- & aNn & 0 & $0 L I$ & $0 \varepsilon^{-}$ & 002 & 0 & $\mathrm{I} 6 / 8 \mathrm{t} / 0 \mathrm{r}$ & \\
\hline$x$ & $\varepsilon t^{-}$ & $\varsigma^{\prime} z^{-}$ & 09I & $0 z^{-}$ & 09I & $0 S$ & {$[6 / \hbar z / t$} & tน \\
\hline$\lambda$ & $69^{-}$ & $0 z^{*}-$ & $0 L I$ & OS- & $0 L I$ & OI & $I 6 / L Z / 6$ & \\
\hline$\chi$ & $\varsigma^{\circ} 9$ & $0 Z^{\prime} 0$ & $09 I$ & OS & $09 I$ & OI & {$[6 / 6 / t$} & 6 ㄹ‼ \\
\hline syдrüy & ${ }^{y_{S Z}}$ & y & 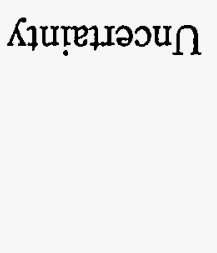 & 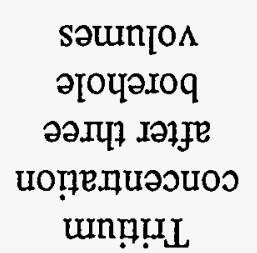 & 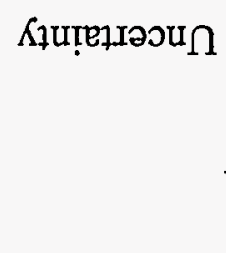 & 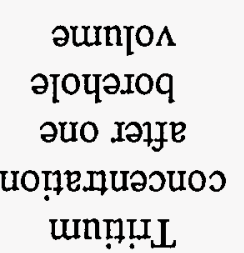 & $\begin{array}{l}\text { pəIdures } \\
\text { әle }\end{array}$ & 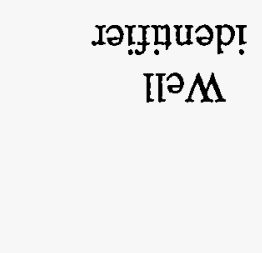 \\
\hline
\end{tabular}

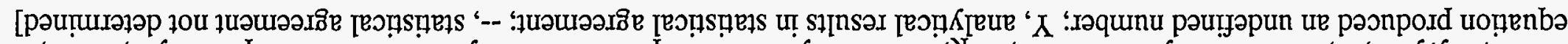

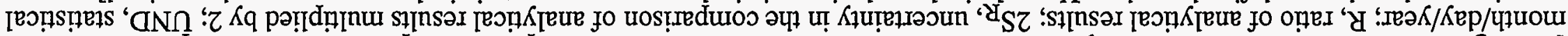

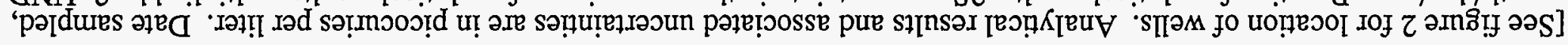

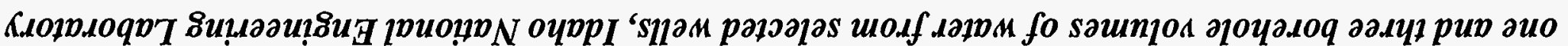

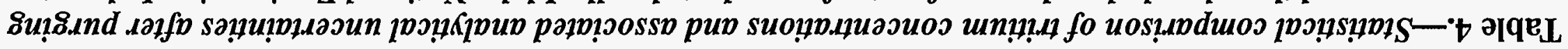


Table 4.-Statistical comparison of tritium concentrations and associated analytical uncertainties after purging one and three borehole volumes of water from selected wells, Idaho National Engineering Laboratory-Continued

\begin{tabular}{|c|c|c|c|c|c|c|c|c|}
\hline $\begin{array}{l}\text { Well } \\
\text { identifier }\end{array}$ & $\begin{array}{l}\text { Date } \\
\text { sampled }\end{array}$ & $\begin{array}{c}\text { Tritium } \\
\text { concentratior } \\
\text { after one } \\
\text { borehole } \\
\text { volume }\end{array}$ & Uncertainty & $\begin{array}{c}\text { Tritium } \\
\text { concentration } \\
\text { after three } \\
\text { borehole } \\
\text { volumes }\end{array}$ & Uncertainty & $\mathrm{R}$ & $2 S_{R}$ & Remarks \\
\hline 82 & $\begin{array}{l}3 / 27 / 91 \\
10 / 23 / 91\end{array}$ & $\begin{array}{r}1,100 \\
150\end{array}$ & $\begin{array}{l}200 \\
170\end{array}$ & $\begin{array}{r}1,100 \\
100\end{array}$ & $\begin{array}{l}200 \\
200\end{array}$ & $\begin{array}{l}1.0 \\
1.5\end{array}$ & $\begin{array}{c}.51 \\
6.9\end{array}$ & $\begin{array}{l}\mathrm{Y} \\
\mathrm{Y}\end{array}$ \\
\hline 83 & $\begin{array}{l}3 / 25 / 91 \\
10 / 1 / 91\end{array}$ & $\begin{array}{l}-50 \\
100\end{array}$ & $\begin{array}{l}160 \\
200\end{array}$ & $\begin{array}{r}20 \\
0\end{array}$ & $\begin{array}{l}160 \\
200\end{array}$ & ${ }^{-2.5}$ & $\begin{array}{r}-43 \\
\text { UND }\end{array}$ & $\begin{array}{l}Y \\
--\end{array}$ \\
\hline 107 & $\begin{array}{l}4 / 22 / 91 \\
9 / 30 / 91\end{array}$ & $\begin{array}{l}110 \\
100\end{array}$ & $\begin{array}{l}160 \\
200\end{array}$ & $\begin{array}{r}-70 \\
0\end{array}$ & $\begin{array}{l}160 \\
170\end{array}$ & $\begin{array}{l}-1.6 \\
\text { UND }\end{array}$ & $\begin{array}{l}-8.7 \\
\text { UND }\end{array}$ & $\begin{array}{l}\mathrm{Y} \\
--\end{array}$ \\
\hline 110 & $\begin{array}{l}3 / 26 / 91 \\
10 / 7 / 91\end{array}$ & $\begin{array}{r}210 \\
-150\end{array}$ & $\begin{array}{l}170 \\
160\end{array}$ & $\begin{array}{r}20 \\
-30\end{array}$ & $\begin{array}{l}160 \\
170\end{array}$ & $\begin{array}{c}10 \\
5.0\end{array}$ & $\begin{array}{r}160 \\
58\end{array}$ & $\begin{array}{l}\mathrm{Y} \\
\mathrm{Y}\end{array}$ \\
\hline 119 & $\begin{array}{l}4 / 19 / 91 \\
10 / 15 / 91\end{array}$ & $\begin{array}{r}70 \\
150\end{array}$ & $\begin{array}{l}160 \\
170\end{array}$ & $\begin{array}{r}0 \\
-140\end{array}$ & $\begin{array}{l}160 \\
160\end{array}$ & $\begin{array}{l}\text { UND } \\
-1.1\end{array}$ & $\begin{array}{l}\text { UND } \\
\quad 3.5\end{array}$ & $\bar{Y}$ \\
\hline
\end{tabular}


Table 5.-Statistical comparison of tritium concentrations and associated analytical uncertainties after purging two and three borehole volumes of water from selected wells, Idaho National Engineering Laboratory

[See figure 2 for location of wells. Analytical results and associated uncertainties are in picocuries per liter. Date sampled, month/day/year; $R$, ratio of analytical results; $2 S_{R}$, uncertainty in the comparison of analytical results multiplied by 2 ; UND, statistical equation produced an undefined number; $N$, analytical results not in statistical agreement; $Y$, analytical results in statistical agreement; -- , statistical agreement not determined]

\begin{tabular}{|c|c|c|c|c|c|c|c|c|}
\hline $\begin{array}{c}\text { Well } \\
\text { identifier }\end{array}$ & $\begin{array}{c}\text { Date } \\
\text { sampled }\end{array}$ & $\begin{array}{l}\text { Tritium } \\
\text { concentration } \\
\text { after two } \\
\text { borehole } \\
\text { volumes }\end{array}$ & Uncertainty & $\begin{array}{c}\text { Tritium } \\
\text { concentration } \\
\text { after three } \\
\text { borehole } \\
\text { volumes }\end{array}$ & Uncertainty & $\mathrm{R}$ & $2 S_{R}$ & Remarks \\
\hline Site 9 & $\begin{array}{l}4 / 9 / 91 \\
9 / 27 / 91\end{array}$ & $\begin{array}{r}-110 \\
10\end{array}$ & $\begin{array}{l}160 \\
170\end{array}$ & $\begin{array}{r}50 \\
-50\end{array}$ & $\begin{array}{l}160 \\
170\end{array}$ & $\begin{array}{l}-2.2 \\
-.20\end{array}$ & $\begin{array}{r}-15.5 \\
-6.9\end{array}$ & $\begin{array}{l}Y \\
Y\end{array}$ \\
\hline Site 14 & $\begin{array}{l}4 / 24 / 91 \\
10 / 18 / 91\end{array}$ & $\begin{array}{l}170 \\
100\end{array}$ & $\begin{array}{l}170 \\
200\end{array}$ & $\begin{array}{l}-20 \\
-30\end{array}$ & $\begin{array}{l}160 \\
170\end{array}$ & $\begin{array}{l}-8.5 \\
-3.3\end{array}$ & $\begin{array}{r}-140 \\
-40\end{array}$ & $\begin{array}{l}Y \\
Y\end{array}$ \\
\hline Site 19 & $\begin{array}{l}4 / 2 / 91 \\
10 / 22 / 91\end{array}$ & $\begin{array}{r}-40 \\
0\end{array}$ & $\begin{array}{l}160 \\
200\end{array}$ & $\begin{array}{r}-50 \\
10\end{array}$ & $\begin{array}{l}160 \\
170\end{array}$ & $0^{.80}$ & $\begin{array}{l}8.2 \\
\text { UND }\end{array}$ & $\begin{array}{l}Y \\
--\end{array}$ \\
\hline 59 & $\begin{array}{l}4 / 4 / 91 \\
10 / 21 / 91\end{array}$ & $\begin{array}{r}6,300 \\
18,900\end{array}$ & $\begin{array}{l}300 \\
600\end{array}$ & $\begin{array}{r}4,900 \\
19,300\end{array}$ & $\begin{array}{l}300 \\
600\end{array}$ & $\begin{array}{l}1.3 \\
.98\end{array}$ & $\begin{array}{l}.20 \\
.09\end{array}$ & $\begin{array}{l}\mathrm{N} \\
\mathrm{Y}\end{array}$ \\
\hline
\end{tabular}


Table 5.-Statistical comparison of tritium concentrations and associated analytical uncertainties after purging two and three borehole volumes of water from selected wells, Idaho National Engineering Laboratory-Continued

\begin{tabular}{|c|c|c|c|c|c|c|c|c|}
\hline $\begin{array}{c}\text { Well } \\
\text { identifier }\end{array}$ & $\begin{array}{l}\text { Date } \\
\text { sampled }\end{array}$ & $\begin{array}{c}\text { Tritium } \\
\text { concentration } \\
\text { after two } \\
\text { borehole } \\
\text { volumes }\end{array}$ & Uncertainty & $\begin{array}{c}\text { Tritium } \\
\text { concentration } \\
\text { after three } \\
\text { borehole } \\
\text { volumes }\end{array}$ & Uncertainty & $\mathbf{R}$ & $2 S_{R}$ & Remarks \\
\hline 82 & $\begin{array}{l}3 / 27 / 91 \\
10 / 23 / 91\end{array}$ & $\begin{array}{r}1,200 \\
150\end{array}$ & $\begin{array}{l}200 \\
170\end{array}$ & $\begin{array}{r}1,100 \\
100\end{array}$ & $\begin{array}{l}200 \\
200\end{array}$ & $\begin{array}{l}1.1 \\
1.5\end{array}$ & $\begin{array}{c}.54 \\
6.9\end{array}$ & $\begin{array}{l}\mathrm{Y} \\
\mathrm{Y}\end{array}$ \\
\hline 83 & $\begin{array}{l}3 / 25 / 91 \\
10 / 1 / 91\end{array}$ & $\begin{array}{l}-50 \\
-80\end{array}$ & $\begin{array}{l}160 \\
170\end{array}$ & $\begin{array}{r}20 \\
0\end{array}$ & $\begin{array}{l}160 \\
200\end{array}$ & $\mathrm{UND}^{-2.5}$ & $\begin{array}{r}-43 \\
\text { UND }\end{array}$ & $\begin{array}{l}\mathrm{Y} \\
--\end{array}$ \\
\hline 107 & $\begin{array}{l}4 / 22 / 91 \\
9 / 30 / 91\end{array}$ & $\begin{array}{r}60 \\
-80\end{array}$ & $\begin{array}{l}160 \\
170\end{array}$ & $\begin{array}{r}-70 \\
0\end{array}$ & $\begin{array}{l}160 \\
170\end{array}$ & $\mathrm{UND}^{-.86}$ & $\begin{array}{l}-6.0 \\
\mathrm{UND}\end{array}$ & $\begin{array}{l}Y \\
--\end{array}$ \\
\hline 110 & $\begin{array}{l}3 / 26 / 91 \\
10 / 7 / 91\end{array}$ & $\begin{array}{r}-170 \\
100\end{array}$ & $\begin{array}{l}150 \\
200\end{array}$ & $\begin{array}{r}20 \\
-30\end{array}$ & $\begin{array}{l}160 \\
170\end{array}$ & $\begin{array}{l}-8.5 \\
-3.3\end{array}$ & $\begin{array}{r}-140 \\
-40\end{array}$ & $\begin{array}{l}\mathrm{Y} \\
\mathrm{Y}\end{array}$ \\
\hline 119 & $\begin{array}{l}4 / 19 / 91 \\
10 / 15 / 91\end{array}$ & $\begin{array}{r}150 \\
-130\end{array}$ & $\begin{array}{l}170 \\
160\end{array}$ & $\begin{array}{r}0 \\
-140\end{array}$ & $\begin{array}{l}160 \\
160\end{array}$ & $\begin{array}{l}\text { UND }^{9} \\
\end{array}$ & $\begin{array}{l}\text { UND } \\
\quad 3.1\end{array}$ & $\bar{Y}$ \\
\hline
\end{tabular}


Table 6.-Statistical comparison of strontium-90 concentrations and associated analytical uncertainties after purging one and three borehole volumes of water from selected wells, Idaho National Engineering Laboratory

[See figure 2 for location of wells. Analytical results and associated uncertainties are in picocuries per liter. Date sampled,

month/day/year; $R$, ratio of analytical results; $2 S_{R}$, uncertainty in the comparison of analytical results multiplied by 2; UND, indicates statistical equation produced an undefined number; $\mathrm{N}$, analytical results not in statistical agreement; $\mathrm{Y}$, analytical results in statistical agreement; --, statistical agreement not determined]

\begin{tabular}{|c|c|c|c|c|c|c|c|c|}
\hline $\begin{array}{c}\text { Well } \\
\text { identifier }\end{array}$ & $\begin{array}{c}\text { Date } \\
\text { sampled }\end{array}$ & $\begin{array}{c}\text { Strontium-90 } \\
\text { concentration } \\
\text { after one } \\
\text { borehole } \\
\text { volume }\end{array}$ & Uncertainty & $\begin{array}{l}\text { Strontium-90 } \\
\text { concentration } \\
\text { after three } \\
\text { borehole } \\
\text { volumes }\end{array}$ & Uncertainty & $\mathrm{R}$ & $2 S_{R}$ & Remarks \\
\hline Site 9 & $\begin{array}{l}4 / 9 / 91 \\
9 / 27 / 91\end{array}$ & $\begin{array}{l}-0.2 \\
-5\end{array}$ & $\begin{array}{l}1.5 \\
2\end{array}$ & $\begin{array}{l}-0.8 \\
-6\end{array}$ & $\begin{array}{l}1.5 \\
2\end{array}$ & $\begin{array}{r}0.25 \\
.83\end{array}$ & $\begin{array}{c}3.9 \\
.86\end{array}$ & $\begin{array}{l}Y \\
Y\end{array}$ \\
\hline Site 14 & $\begin{array}{l}4 / 24 / 91 \\
10 / 18 / 91\end{array}$ & $\begin{array}{c}-1.6 \\
0\end{array}$ & $\begin{array}{l}1.8 \\
2\end{array}$ & $\begin{array}{l}0 \\
1.3\end{array}$ & $\begin{array}{l}2 \\
2.4\end{array}$ & $\begin{array}{r}\text { UND } \\
0\end{array}$ & $\begin{array}{l}\text { UND } \\
\text { UND }\end{array}$ & -- \\
\hline Site 19 & $\begin{array}{l}4 / 2 / 91 \\
10 / 22 / 91\end{array}$ & $\begin{array}{l}1.7 \\
0\end{array}$ & $\begin{array}{l}2.0 \\
2\end{array}$ & $\begin{array}{r}1.1 \\
-1.3\end{array}$ & $\begin{array}{l}1.9 \\
2.3\end{array}$ & $\begin{array}{l}1.5 \\
0\end{array}$ & UND $^{6.3}$ & $\begin{array}{c}Y \\
--\end{array}$ \\
\hline TRA Disposal & $10 / 30 / 91$ & -.9 & 1.7 & -.4 & 1.5 & 2.2 & 18 & $\mathrm{Y}$ \\
\hline 38 & $\begin{array}{l}4 / 22 / 91 \\
10 / 3 / 91\end{array}$ & $\begin{array}{l}26 \\
23\end{array}$ & $\begin{array}{l}3 \\
3\end{array}$ & $\begin{array}{r}29 \\
9\end{array}$ & $\begin{array}{l}3 \\
3\end{array}$ & $\begin{array}{l}.90 \\
2.6\end{array}$ & $\begin{array}{l}.28 \\
1.9\end{array}$ & $\begin{array}{l}\mathrm{Y} \\
\mathrm{Y}\end{array}$ \\
\hline 59 & $\begin{array}{l}4 / 4 / 91 \\
10 / 21 / 91\end{array}$ & $\begin{array}{l}13 \\
18\end{array}$ & $\begin{array}{l}3 \\
3\end{array}$ & $\begin{array}{l}13 \\
14\end{array}$ & $\begin{array}{l}3 \\
2\end{array}$ & $\begin{array}{l}1.0 \\
1.3\end{array}$ & $\begin{array}{l}.65 \\
.57\end{array}$ & $\begin{array}{l}Y \\
Y\end{array}$ \\
\hline
\end{tabular}


Table 6.-Statistical comparison of strontium-90 concentrations and associated analytical uncertainties after purging one and three borehole volumes of water from selected wells, Idaho National Engineering Laboratory-Continued

\begin{tabular}{|c|c|c|c|c|c|c|c|c|}
\hline $\begin{array}{l}\text { Well } \\
\text { identifier }\end{array}$ & $\begin{array}{l}\text { Date } \\
\text { sampled }\end{array}$ & $\begin{array}{l}\text { Strontium- } 90 \\
\text { concentration } \\
\text { after one } \\
\text { borehole } \\
\text { volume }\end{array}$ & Uncertainty & $\begin{array}{c}\text { Strontium-90 } \\
\text { concentration } \\
\text { after three } \\
\text { borehole } \\
\text { volumes }\end{array}$ & Uncertainty & $\mathrm{R}$ & $2 S_{R}$ & Remarks \\
\hline 82 & $\begin{array}{l}3 / 27 / 91 \\
10 / 23 / 91\end{array}$ & $\begin{array}{l}-3.1 \\
-1\end{array}$ & $\begin{array}{l}1.7 \\
2\end{array}$ & $\begin{array}{r}8 \\
-2\end{array}$ & $\begin{array}{l}2 \\
2\end{array}$ & $\begin{array}{r}-.39 \\
.50\end{array}$ & $\begin{array}{l}-.47 \\
2.2\end{array}$ & $\begin{array}{l}\mathrm{N} \\
\mathrm{Y}\end{array}$ \\
\hline 83 & $\begin{array}{l}3 / 25 / 91 \\
10 / 1 / 91\end{array}$ & $\begin{array}{l}-3.7 \\
-1.4\end{array}$ & $\begin{array}{l}1.5 \\
1.9\end{array}$ & $\begin{array}{l}-3.8 \\
-2\end{array}$ & $\begin{array}{l}1.5 \\
2\end{array}$ & $\begin{array}{l}.97 \\
.70\end{array}$ & $\begin{array}{l}1.1 \\
2.4\end{array}$ & $\begin{array}{l}\mathrm{Y} \\
\mathrm{Y}\end{array}$ \\
\hline 107 & $\begin{array}{l}4 / 22 / 91 \\
9 / 30 / 91\end{array}$ & $\begin{array}{r}-1 \\
1\end{array}$ & $\begin{array}{l}2 \\
2\end{array}$ & $\begin{array}{r}-1 \\
2\end{array}$ & $\begin{array}{l}2 \\
2\end{array}$ & $\begin{array}{c}1.0 \\
.50\end{array}$ & $\begin{array}{l}5.7 \\
2.2\end{array}$ & $\begin{array}{l}\mathrm{Y} \\
\mathrm{Y}\end{array}$ \\
\hline 110 & $\begin{array}{l}3 / 26 / 91 \\
10 / 7 / 91\end{array}$ & $\begin{array}{l}-3.6 \\
-1\end{array}$ & $\begin{array}{l}1.7 \\
2\end{array}$ & $\begin{array}{r}-3 \\
0\end{array}$ & $\begin{array}{l}2 \\
2\end{array}$ & $\mathrm{UND}^{1.2}$ & $\mathrm{UND}^{2.0}$ & $\begin{array}{l}Y \\
--\end{array}$ \\
\hline 119 & $\begin{array}{l}4 / 19 / 91 \\
10 / 15 / 91\end{array}$ & $-1^{.7}$ & $\begin{array}{l}1.7 \\
2\end{array}$ & $\begin{array}{l}4 \\
1.4\end{array}$ & $\begin{array}{l}2 \\
2.1\end{array}$ & $\begin{array}{r}.18 \\
-.71\end{array}$ & $\begin{array}{l}.89 \\
-3.6\end{array}$ & $\begin{array}{l}\mathrm{Y} \\
\mathrm{Y}\end{array}$ \\
\hline
\end{tabular}


Table 7.-Statistical comparison of strontium-90 concentrations and associated analytical uncertainties after purging two and three borehole volumes of water from selected wells, Idaho National Engineering Laboratory

[See figure 2 for location of wells. Analytical results and associated uncertainties are in picocuries per liter. Date sampled, month/day/year, $R$, ratio of analytical results; $2 S_{R}$, uncertainty in the comparison of analytical results multiplied by 2 ; UND, statistical equation produced an undefined number; $\mathrm{Y}$, analytical results in statistical agreement; --, statistical agreement not determined]

\begin{tabular}{|c|c|c|c|c|c|c|c|c|}
\hline $\begin{array}{l}\text { Well } \\
\text { identifier }\end{array}$ & $\begin{array}{c}\text { Date } \\
\text { sampled }\end{array}$ & $\begin{array}{c}\text { Strontium-90 } \\
\text { concentration } \\
\text { after two } \\
\text { borehole } \\
\text { volumes }\end{array}$ & Uncertainty & $\begin{array}{l}\text { Strontium-90 } \\
\text { concentration } \\
\text { after three } \\
\text { borehole } \\
\text { volumes }\end{array}$ & Uncertainty & $\mathrm{R}$ & $2 S_{R}$ & Remarks \\
\hline Site 9 & $\begin{array}{l}4 / 9 / 91 \\
9 / 27 / 91\end{array}$ & $\begin{array}{l}0.7 \\
-6\end{array}$ & $\begin{array}{l}1.6 \\
2\end{array}$ & $\begin{array}{l}-0.8 \\
-6\end{array}$ & $\begin{array}{l}1.5 \\
2\end{array}$ & $\begin{array}{c}-0.88 \\
1.0\end{array}$ & $\begin{array}{r}-5.2 \\
.94\end{array}$ & $\begin{array}{l}\mathrm{Y} \\
\mathrm{Y}\end{array}$ \\
\hline Site 14 & $\begin{array}{l}4 / 24 / 91 \\
10 / 18 / 91\end{array}$ & $\begin{array}{l}0 \\
1\end{array}$ & $\begin{array}{l}2 \\
2\end{array}$ & $\begin{array}{l}0 \\
1.3\end{array}$ & $\begin{array}{l}2 \\
2.4\end{array}$ & $\begin{array}{l}\text { UND } \\
.77\end{array}$ & $\begin{array}{l}\text { UND } \\
4.2\end{array}$ & $\bar{Y}$ \\
\hline Site 19 & $\begin{array}{l}4 / 2 / 91 \\
10 / 22 / 91\end{array}$ & $\begin{array}{l}3 \\
4\end{array}$ & $\begin{array}{l}2 \\
2\end{array}$ & $\begin{array}{r}1.1 \\
-1.3\end{array}$ & $\begin{array}{l}1.9 \\
2.3\end{array}$ & $\begin{array}{r}2.7 \\
-3.1\end{array}$ & $\begin{array}{r}10 \\
-11\end{array}$ & $\begin{array}{l}Y \\
Y\end{array}$ \\
\hline TRA Disposal & $10 / 30 / 91$ & .8 & 1.6 & -.4 & 1.5 & -2.0 & -17 & $\mathrm{Y}$ \\
\hline 38 & $\begin{array}{l}4 / 22 / 91 \\
10 / 3 / 91\end{array}$ & $\begin{array}{l}28 \\
27\end{array}$ & $\begin{array}{l}3 \\
5\end{array}$ & $\begin{array}{r}29 \\
9\end{array}$ & $\begin{array}{l}3 \\
3\end{array}$ & $\begin{array}{l}.97 \\
3.0\end{array}$ & $\begin{array}{l}.29 \\
2.3\end{array}$ & $\begin{array}{l}Y \\
Y\end{array}$ \\
\hline 59 & $\begin{array}{l}4 / 4 / 91 \\
10 / 21 / 91\end{array}$ & $\begin{array}{l}16 \\
17\end{array}$ & $\begin{array}{l}3 \\
3\end{array}$ & $\begin{array}{l}13 \\
14\end{array}$ & $\begin{array}{l}3 \\
2\end{array}$ & $\begin{array}{l}1.2 \\
1.2\end{array}$ & $\begin{array}{l}.71 \\
.54\end{array}$ & $\begin{array}{l}\mathrm{Y} \\
\mathrm{Y}\end{array}$ \\
\hline
\end{tabular}


Table 7.-Statistical comparison of strontium-90 concentrations and associated analytical uncertainties after purging two and three borehole volumes of water from selected wells, Idaho National Engineering Laboratory-Continued

\begin{tabular}{|c|c|c|c|c|c|c|c|c|}
\hline $\begin{array}{c}\text { Well } \\
\text { identifier }\end{array}$ & $\begin{array}{l}\text { Date } \\
\text { sampled }\end{array}$ & $\begin{array}{c}\text { Strontium-90 } \\
\text { concentration } \\
\text { after two } \\
\text { borehole } \\
\text { volumes }\end{array}$ & Uncertainty & $\begin{array}{c}\text { Strontium-90 } \\
\text { concentration } \\
\text { after three } \\
\text { borehole } \\
\text { volumes }\end{array}$ & Uncertainty & $\mathrm{R}$ & $2 S_{R}$ & Remarks \\
\hline 82 & $\begin{array}{l}3 / 27 / 91 \\
10 / 23 / 91\end{array}$ & $\begin{array}{c}0 \\
-1.2\end{array}$ & $\begin{array}{l}2 \\
2.1\end{array}$ & $\begin{array}{r}8 \\
-2\end{array}$ & $\begin{array}{l}2 \\
2\end{array}$ & $\begin{array}{l}0 \\
.60\end{array}$ & $\begin{array}{l}\text { UND } \\
2.4\end{array}$ & $\bar{Y}$ \\
\hline 83 & $\begin{array}{l}3 / 25 / 91 \\
10 / 1 / 91\end{array}$ & $\begin{array}{l}-4.4 \\
-2\end{array}$ & $\begin{array}{l}1.5 \\
2\end{array}$ & $\begin{array}{l}-3.8 \\
-2\end{array}$ & $\begin{array}{l}1.5 \\
2\end{array}$ & $\begin{array}{l}1.2 \\
1.0\end{array}$ & $\begin{array}{l}1.3 \\
2.8\end{array}$ & $\begin{array}{l}\mathrm{Y} \\
\mathrm{Y}\end{array}$ \\
\hline 107 & $\begin{array}{l}4 / 22 / 91 \\
9 / 30 / 91\end{array}$ & $\begin{array}{r}-1 \\
1\end{array}$ & $\begin{array}{l}2 \\
2\end{array}$ & $\begin{array}{r}-1 \\
2\end{array}$ & $\begin{array}{l}2 \\
2\end{array}$ & $\begin{array}{c}1.0 \\
.50\end{array}$ & $\begin{array}{l}5.7 \\
2.2\end{array}$ & $\begin{array}{l}\mathrm{Y} \\
\mathrm{Y}\end{array}$ \\
\hline 110 & $\begin{array}{l}3 / 26 / 91 \\
10 / 7 / 91\end{array}$ & $\begin{array}{l}-1.2 \\
-1.0\end{array}$ & $\begin{array}{l}2.0 \\
2.2\end{array}$ & $\begin{array}{r}-3 \\
0\end{array}$ & $\begin{array}{l}2 \\
2\end{array}$ & $\mathrm{UND}^{.40}$ & $\mathrm{UND}^{1.4}$ & $\begin{array}{l}\mathrm{Y} \\
--\end{array}$ \\
\hline 119 & $\begin{array}{l}4 / 19 / 91 \\
10 / 15 / 91\end{array}$ & $\begin{array}{r}0 \\
-3\end{array}$ & $\begin{array}{l}1.6 \\
2\end{array}$ & $\begin{array}{l}4 \\
1.4\end{array}$ & $\begin{array}{l}2 \\
2.1\end{array}$ & $\begin{array}{c}0 \\
-2.1\end{array}$ & $\begin{array}{l}\text { UND } \\
-6.9\end{array}$ & $\bar{Y}$ \\
\hline
\end{tabular}

